\title{
KEMISKINAN NELAYAN TRADISIONAL SERTA DAMPAKNYA TERHADAP PERKEMBANGAN KUMUH
}

\author{
Goso $^{1}$, Suhardi M. Anwar ${ }^{2}$ \\ Sekolah Tinggi Ilmu Ekonomi Muhammadiyah Palopo \\ ${ }^{1}$ E_Mail: goso@stiem.ac.id \\ ${ }^{2}$ E_Mail: mansuhardi@stiem.ac.id
}

\begin{abstract}
Abstrak: Komunitas bangsa Indonesia yang teridentifikasi sebagai golongan miskin saat ini adalah nelayan, di mana 14,58 juta jiwa atau 90 persen dari 16,2 juta jumlah nelayan di Indonesia berada di bawah garis kemiskinan. Di Kelurahan Ponjalae dan Tapong terdapat 51 Kepala Keluarga bekerja sebagai nelayan tradisional tergolong ke dalamkelompok masyarakat miskin. Penelitian ditujukan untuk mengetahuifaktor-faktor penyebab dan bentuk kemiskinan nelayan tradisional di Kelurahan Ponjalae dan Tapong, dengan metode deskriptif kualitatif menggunakan data primer dan sekunder. Data primer dikumpulkan dengan menyebarkan kuesioner, wawancara dan pengamatan. Data sekunder dilakukan dengan mengumpulkan dokumen-dokumen terkait topic penelitian. Kehadiran lembaga ekonomi seperti koperasi belum sepenuhnya dapat membantu peningkatan taraf hidup nelayan tradisional. Hal ini ditandai dengan tidak adanya akses nelayan tradisional terhadap lembaga tersebut dalam memperoleh modal usaha. Ditambah lagi dengan pendapatan mereka yang tidak menentu membuat nelayan tergatung kepada pemilik modal yang tidak hanya sebatas kebutuhan modal usaha dan alat produksi, malah sampai kepada biaya kebutuhan hidup keluarga sehari-hari. Hasil penelitian mengkonfirmasi factor-faktor yang berpengaruh terhadap kemiskinan nelayan tradisional penyebab perkampungan kumuh kota yaitu; factor kualitas sumber dayamanusia; factor ekonomi; dan factor kelembagaan. Bentuk kemiskinan yang terjadi di masyarakat kumuh Kota Palopo adalah kemiskinan natural dan kultural.
\end{abstract}

Kata kunci: Masalah Kemiskinan, Kemiskinan Natural dan kemiskinan Kultural, Bentuk Kemiskinan, Nelayan Tradisional, Perkampungan Kumuh Kota

\section{PENDAHULUAN}

Pembangunan seharusnya dijadikan sebagai arena dalam perluasan kebebasan subtantif (subtantive freedom) bagi setiap orang. Artinya pembangunan yang bersumber non-kebebasan (nonfreedom sources) harus disingkirkan, yakni kemiskinan dan tirani, minimnya peluang ekonomi dan kemiskinan sosial sistematis, penelantaran sarana umum dan intoleransi serta campur tangan rezim refresif yang berlebihan (Sen dalam Teddy, 2007: 1).

Pandangan tersebut mengisyaratkan bahwa tantangan pembangunan adalah memperbaiki kualitas kehidupan. Terutama di negara-negara yang paling miskin. Kualitas hidup yang baik memang mensyaratkan adanya pendapatan yang lebih tinggi, namun yang dibutuhkan bukan hanya itu. Pendapatan yang lebih tinggi itu hanya merupakan salah satu dari kesekian banyak syarat yang harus dipenuhi. Banyak hal-hal lain yang tidak kalah pentingnya yang juga harus diperjuangkan, yakni mulai dari pendidikan yang lebih baik, peningkatan standar kesehatan dan nutrisi, pemberantasan kemiskinan, perbaikan lingkungan hidup, pemerataan kesempatan, pemerataan kebebasan individual dan penyegaran kehidupan budaya (Bank Dunia dalam Tadaro, 2000: 19).

Kemiskinan merupakan fenomena social yang sering terjadi, kemiskinan pada umumnya ditandai dengan derita keterbelakangan, ketertinggalan, rendahnya produktivitas, selanjutnya menjadi rendahnya pendapatan yang diterima. Krisis ekonomi yang terjadi di tahun 
1998 telah mengakibatkan meningkatnya jumlah penduduk miskin di Indonesia secara drastis. Pada tahun 1998 jumlah penduduk miskin meningkat menjadi 49,5 juta jiwa atau sekitar 24,2 persen dari seluruh penduduk. Dan pada tahun 2004 jumlah penduduk miskin di Indonesia masih mencapai 36,2 juta jiwa atau sekitar 16,7 persen dari seluruh penduduk (Kuncoro, 2006: 117). Selanjutnya pada tahun 2004-2008, angka penduduk miskin di Indonesia adalah: tahun 2005 sebesar 35,1 juta jiwa atau 15,97 persen. Kondisi ini memburuk di tahun 2006 jumlah penduduk miskin meningkat menjadi 39,3 juta jiwa atau 17,75 persen, yang disebabkan oleh tingginya tingkat inflasi dan kenaikan harga BBM. Namun berangsur-angsur kondisi ini terus membaik. Jumlah penduduk miskin di Indonesia pada bulan Maret 2008 sebesar 34,96 juta jiwa atau 15,42 persen. Jumlah penduduk miskin sudah berkurang sebesar 2,21 juta jiwa dibandingkan dengan jumlah penduduk miskin pada bulan Maret 2007, yang berjumlah 37,17 juta jiwa atau 16,58 persen (Sensenas, 2008).

Salah satu komunitas bangsa Indonesia yang teridentifikasi sebagai golongan miskin saat ini adalah nelayan, di mana sedikitnya 14,58 juta jiwa atau sekitar 90 persen dari 16,2 juta jumlah nelayan di Indonesia masih berada di bawah garis kemiskinan (Martadiningrat dalam Antara, 2008: 1). Padahal negara Indonesia adalah negara bahari yang pulau-pulaunya di kelilingi oleh lautan yang di dalamnya mengandung berbagai potensi ekonomi khususnya di bidang perikanan, namun sampai saat ini kehidupan nelayan tetap saja masih berada dalam jurang kemiskinan.
Di sisi lain nelayan mempunyai peran yang sangat substansial dalam modernisasi kehidupan manusia. Mereka termasuk agent of development yang paling reaktif terhadap lingkungan. Sifatnya yang lebih terbuka jika dibandingkan dengan kelompok masyarakat yang hidup di pedalaman, menjadi stimulator untuk menerima perkembangan peradaban yang lebih modern (Sudrajad, 2008: 2). Namun dalam perkembangannya, justru nelayan belum menunjukkan kemajuan yang berarti sebagaimana kelompok masyarakat yang lain. Keberadaan mereka sebagai agent of development ternyata tidak ditunjukkan secara positif dengan kehidupan ekonominya. Salah satu golongan nelayan yang menerima efek langsung oleh krisis tersebut adalah nelayan tradisional boleh dikatakan adalah kelompok masyarakat pesisir yang paling menderita dan merupakan korban pertama dari perubahan situasi sosial ekonomi yang datangnya tiba-tiba dan berkepanjangan (Sudarso, 2008: 1). Sedangkan bila dilihat dari tempat tinggalnya, pada umumnya nelayan tradisional berada dalam lingkungan sumberdaya laut yang kaya raya, namun mereka miskin. Sehingga Sudjatmoko (1995: 47) menyatakan kemiskinan yang terjadi pada nelayan tradisional adalah kemiskinan struktural.

Kehidupan mereka sungguh memprihatinkan karena sebagai nelayan tradisional yang tergolong ke dalam kelompok masyarakat miskin mereka seringkali dijadikan objek ekploitatif oleh para pemilik modal. Harga ikan sebagai sumber pendapatannya dikendalikan oleh para pemilik modal atau para pedagang/tengkulak, sehingga distribusi pendapatan menjadi tidak merata. 
Gejala modernisasi perikanan tidak banyak membantu bahkan membuat nelayan tradisional terpinggirkan, seperti munculnya kapal tangkap yang berukuran besar dan teknologi moderen. Mereka mampu menangkap ikan lebih banyak dibandingkan nelayan tradisional yang hanya menggunakan teknologi konvensional. Penelitian ini bertujuan untuk mencari penyebab kemiskinan nelayan dan bentuk kemiskinan yang terjadai pada nelayan tradisional.

\section{KAJIAN LITERATUR DAN PENGEMBANGAN HIPOTESIS}

Kajian kemiskinan yang dikemukakan oleh Friedmann (1992: 89) adalah sebagai berikut:

1) Powerty line (garis kemiskinan). Yaitu tingkat konsumsi rumah tangga minimum yang dapat diterima secara sosial. Ia biasanya dihitung berdasarkan income yang dua pertiganya digunakan untuk "keranjang pangan" yang dihitung oleh ahli statistik kesejahteraan sebagai persediaan kalori dan protein utama yang paling murah.

2) Absolute and relative poverty (kemiskinan absolut dan relatif). Kemiskinan absolut adalah kemiskinan yang jatuh di bawah standar konsumsi minimum dan karenanya tergantung pada kebaikan (karitas/amal). Sedangkan relatif adalah kemiskinan yang eksis di atas garis kemiskinan absolut yang sering dianggap sebagai kesenjangan antara kelompok miskin dan kelompok non miskin berdasarkan income relatif.

3) Deserving poor adalah kaum miskin yang mau peduli dengan harapan orang-orang nonmiskin, bersih, bertanggung jawab, mau menerima pekerjaan apa saja demi memperoleh upah yang ditawarkan.

4) Target population adalah kelompok orang tertentu yang dijadikan sebagai objek dan kebijakan serta program pemerintah. Mereka dapat berupa rumah tangga yang dikepalai perempuan, anak-anak, buruh tani yang tak punya lahan, petani tradisional kecil, korban perang dan wabah, serta penghuni kampung kumuh perkotaan.

Friedmann juga merumuskan kemiskinan sebagai minimnya kebutuhan dasar sebagaimana yang dirumuskan dalam konferensi ILO tahun 1976. Kebutuhan dasar menurut konferensi itu dirumuskan sebagai berikut:

1) Kebutuhan minimum dari suatu keluarga akan konsumsi privat (pangan, sandang, papan dan sebagainya).

2) Pelayanan esensial atas konsumsi kolektif yang disediakan oleh dan untuk komunitas pada umumnya (air minum sehat, sanitasi, tenaga listrik, angkutan umum, dan fasilitas kesehatan dan pendidikan).

3) Partisipasi masyarakat dalam pembuatan keputusan yang mempengaruhi mereka.

4) Terpenuhinya tingkat absolut kebutuhan dasar dalam kerangka kerja yang lebih luas dari hakhak dasar manusia.

Penciptaan lapangan kerja (employment) baik sebagai alat maupun tujuan dari strategi kebutuhan dasar.

Kemiskinan bukanlah suatu hal yang dikehendaki, akan tetapi lebih diakibatkan oleh adanya faktor-faktor tertentu yang menyebabkan orang terjebak ke dalam jurang kemiskinan, baik itu berupa faktor alamiah maupun faktor buatan 
manusia itu sendiri. Hardiman dan Midgley (1982) dalam Kuncoro (2006: 119) mengatakan; 'Kemiskinan massal yang terjadi di banyak negara yang baru saja merdeka setelah Perang Dunia ke II memfokuskan pada keterbelakangan dari perekonomian negara tersebut sebagai akar permasalahannya".

Sharp, et,al (1996) mengatakan penyebab kemiskinan bila diidentifikasikan berdasarkan sudut pandang ekonomi adalah: Pertama; secara mikro, kemiskinan muncul karena ketidaksamaan pola kepemilikan sumber daya, yang menimbulkan kontribusi pendapatan yang timpang. Penduduk miskin hanya memiliki sumber daya dalam jumlah terbatas dan kualitasnya rendah. Kedua; kemiskinan muncul akibat perbedaan dalam kualitas sumber daya manusia. Kualitas sumber daya manusia yang rendah berarti produktivitasnya rendah, yang pada gilirannya upahnya rendah. Rendahnya kualitas sumber daya manusia ini karena rendahnya pendidikan, nasib yang kurang beruntung adanya diskrimanasi. Ketiga; kemiskinan muncul akibat perbedaan akses dalam modal. Ketiga penyebab kemiskinan ini menurut Nurske: bermuara pada teori lingkaran setan kemiskinan. Adanya keterbelakangan, ketidaksempurnaan pasar dan kurangnya modal menyebabkan rendahnya produktivitas. Rendahnya produktivitas, mengakibatkan rendahnya pendapatan yang mereka terima. Rendahnya pendapatan akan berimplikasi kapada rendahnya tabungan dan investasi. Rendahnya investasi berakibat kepada keterbelakangan, dan seterusnya.

\section{METODE DAN BAHAN}

Lokasi di kelurahan Ponjalae dan Tapong Kota Palopo Provinsi Sulawesi Selatan, terpilihnya kelurahan Pontap sebagai lokasi penelitian dengan pertimbangan, dari 718 jiwa jumlah penduduk atau 167 kepala keluarga, terdapat 86 kepala keluarga tergolong ke dalam kelompok masyarakat miskin dan dari 86 kepala keluarga miskin 51 kepala keluarga bekerja sebagai nelayan tradisional yang berada di Kecamatan Wara Timur. Data primer di peroleh dari 51 Kepala Keluarga (KK) Nelayan Tradisional, Kepala Dinas Kelautan dan Perikanan, Camat Wara, Kelurahan Ponjalae dan Kelurahan Tapong. Populasi finit, 51 kepala keluarga nelayan tradisional kelurahan Ponjalae dan Tapong (Pontap) Kecamatan Wara Timur.

Untuk mengetahui faktor-faktor penyebab kemiskinan pada nelayan tradisional di Kelurahan Ponjalae dan Tapong, maka pada setiap indikator dari masing-masing faktor diberikan ukuran atau katagori secara kualitatif, yaitu:

\section{1) Faktor kualitas sumber daya manusia}
a. Tingkat pendidikan.
b. Ketrampilan alternatif.
c. Pekerjaan alternatif.

Jika ketiga unsur terpenuhi, dikatagorikan sangat berpengaruh, jika dua unsur terpenuhi dikatagorikan berpengaruh dan jika hanya satu unsur yang terpenuhi dikatagorikan tidak berpengaruh.

\section{2) Faktor ekonomi}
a. Kepemilikan modal usaha.
b. Kepemilikan tanah.
c. Teknologi yang digunakan. 
Jika ketiga unsur terpenuhi, dikatagorikan sangat berpengaruh, jika dua unsur terpenuhi dikatagorikan berpengaruh dan jika hanya satu unsur yang terpenuhi dikatagorikan tidak berpengaruh.

\section{3) Faktor hubungan ke rja nelayan}

a. Ketergantungan modal kerja nelayan pada pemilik modal.

b. Sistem bagi hasil nelayan dengan pemilik modal.

c. Sistem bagi hasil nelayan pemilik perahu dengan nelayan penumpang.

Jika ketiga unsur terpenuhi, dikatagorikan sangat berpengaruh, jika dua unsur terpenuhi dikatagorikan berpengaruh dan jika hanya satu unsur yang terpenuhi dikatagorikan tidak berpengaruh.

\section{4) Faktor kelembagaan}

a. Peranan lembaga pemasaran.

b. Peranan lembaga penyuluhan.

c. Peranan lembaga perkreditan.

Jika ketiga unsur terpenuhi, dikatagorikan sangat berpengaruh, jika dua unsur terpenuhi dikatagorikan berpengaruh dan jika hanya satu unsur yang terpenuhi dikatagorikan tidak berpengaruh.

Untuk mengetahui bentuk-bentuk kemiskinan yang terjadi pada nelayan tradisional di kelurahan Ponjalae dan Tapong Kota Palopo, dianalisis berdasarkan fenomena-fenomena yang terjadi dalam kehidupan nelayan tradisional yang berkaitan dengan kemiskinan nelayan itu sendiri.

1. Nelayan Tradisional adalah orang yang secara aktif melakukan usaha atau berburu ikan di laut yang menggunakan peralatan tangkap tradisional berupa perahu berukuran panjang 5 meter, lebar 1 meter dan tinggi 0,5 meter, kapasitas penumpang maksimum 2 orang dan dijalankan dengan mesin tempel berkapasitas 5,5 PK. Alat tangkap yang digunakan jaring dan pancing.

2. Teknologi adalah alat tangkap yang digunakan oleh nelayan dalam berburu ikan di laut.

3. Tingkat Pendidikan adalah jenjang pendidikan tertinggi yang ditamatkan oleh nelayan.

4. Ukuran garis kemiskinan yang digunakan adalah garis kemiskinan Subjogyo dengan mengasumsikan jumlah tanggungan keluarga sebanyak 4 orang, yang terdiri dari 1 (satu) orang ibu dan 3 (tiga) orang anak.

\section{HASIL DAN PEMBAHASAN}

\section{Tingkat Pendidikan}

Distribusi responden berdasarkan tingkat pendidikan pada aspek dari kualitas sumber daya manusia pada nelayan tradisional

Karakte ristik Responden Menurut Tingkat Pendidikan

\begin{tabular}{l|c|c}
\hline Tingkat Pendidikan & Jumlah & Prosentase \\
\hline Tamat SD/Sederajat & 27 & 53.0 \\
\hline $\begin{array}{l}\text { Tamat SLTP/ } \\
\text { Sederajat }\end{array}$ & 23 & 45.0 \\
\hline $\begin{array}{l}\text { Tamat } \\
\text { SLTA/Sederajat }\end{array}$ & 1 & 2.0 \\
\hline \multicolumn{1}{c|}{ Jumlah } & 51 & 100 \\
\hline
\end{tabular}

Dari 51 nelayan responden yang diteliti terdapat 53 persen responden tamat Sekolah Dasar (SD)/Sederajat, 45 persen responden tamat SLTP. Dan yang lulus Sekolah Lanjutan Tingkat Atas (SLTP) hanya 2 persen. Keadaan tersebut 
menggambarkan bahwa tingkat pendidikan nelayan di Kelurahan Ponjalae dan Tapong sangat rendah

Pendapatan Rata-rata Nelayan Tradisional Per Bulan

\begin{tabular}{c|c|c|}
\hline Jumlah Pendapatan (Rp) & Jumlah & Prosentase \\
\hline$<500.000,-$ & - & 0 \\
\hline $500.000,-$ s/d 750.000,- & 7 & 14 \\
\hline $750.000,-$ s/d 1.000.000,- & 29 & 57 \\
\hline$>1.000 .000,-$ & 15 & 29 \\
\hline Jumlah & 51 & 100 \\
\hline
\end{tabular}

Diketahui 57 persen responden berpendapatan rata-rata antara Rp. 750.000.- s/d Rp. 1.000.000.- per bulan, 29 persen responden berpendapatan antara Rp. 550.000.- s/d Rp. 597.700.- per bulan, dan 14 persen responden berpendapatan antara Rp. $>1.000 .000$.- per bulan. Hal ini menunjukkan pada umumnya rata-rata pendapatan nelayan tradisional di Kelurahan Ponjalae dan Tapong per bulan adalah antara Rp. 750.000.- s/d Rp. 1.000.000.-. Bila pendapatan nelayan tradisional kita ukur dengan menggunakan ukuran garis kemiskinan Sajogyo, di mana perhitungan dilakukan dengan mengasumsikan anggota keluarga sebanyak 5 orang dan harga beras saat dilakukan penelitian berkisar antara Rp. 9.200.- s/d Rp. 10.500.- per kilogram. Adapun garis kemiskinan ini dihitung dengan menggunakan konsep kebutuhan fisik minimum (KFM), yang dipakai oleh Purba (2002: 46-47), yaitu KFM= Kg Beras/12 x JAK x HB. Di mana $\mathrm{KFM}=$ kebutuhan fisik minimum, $\mathrm{JAK}=\mathrm{Jumlah}$ anggota keluarga dan $\mathrm{HB}=$ harga beras saat dilakukan penelitian. Sehingga berdasarkan formula tersebut kebutuhan fisik minimum keluarga nelayan tradisional dapat dihitung sebagai berikut: a. Miskin : 320/12 x 5 x $9.200=$ Rp. 1.226.667.-

b. Miskin sekali : 240/12 × 5 × $9.200=$ Rp. 920.000.-

c. Paling miskin : 180/12 x 5 × $9.200=$ Rp. 690.000.-

Nelayan tradisional dikatagorikan sebagai kelompok masyarakat paling miskin dan miskin sekali. Karena pendapatannya tertinggi nelayan tradisional berada di bawah Rp. 920.000.- yakni Rp. 750.000.- s/d Rp. 1.000.000.- dan >Rp. 1.000.000.-. Hal ini sesuai dengan yang dikatakan oleh Mubyarto (1984: 67) dalam penelitiannya bahwa pada umumnya nelayan merupakan kelompok paling miskin.

\section{Keterampilan alte rnatif}

Dari data yang ditemukan bahwa pada umumnya responden tidak menguasai ketrampilan alternatif. Ini terbukti ketika ditanyakan kepada 51 responden tentang penguasaan ketrampilan selain dari ketrampilan menangkap ikan di laut, 88 persen responden menjawab tidak menguasai ketrampilan alternatif, 4 persen responden menjawab menguasai ketrampilan alternatif berupa ketrampilan pertukangan dan 8 persen responden menguasai ketrampilan di bidang perabotan.

\section{Penguasaan Ke trampilan Alte rnatif (Non Perikanan)}

\begin{tabular}{l|c|c}
\hline \multicolumn{1}{c|}{$\begin{array}{c}\text { Ketrampilan } \\
\text { Alternatif }\end{array}$} & Jumlah & Prosentase \\
\hline $\begin{array}{l}\text { Menguasai ketrampilan } \\
\text { pertukangan }\end{array}$ & 2 & 4 \\
\hline $\begin{array}{l}\text { Menguasai ketrampilan } \\
\text { perabotan }\end{array}$ & 4 & 8 \\
\hline $\begin{array}{l}\text { Tidak menguasai } \\
\text { ketrampilan }\end{array}$ & 45 & 88 \\
\hline \multicolumn{1}{c}{ Jumlah } & 51 & 100 \\
\hline
\end{tabular}




\section{Aspek Kepemilikan Modal}

Pada factor ekonomi aspek kepemilikan modal 100 persen responden tidak memiliki modal untuk pengembangan usaha. Akibatnya nelayan tidak dapat melakukan peningkatan produksi. Sedangkan rendahnya produksi sangat berpengaruh kepada jumlah pendapatan yang diterima. Artinya bila produksi rendah, maka akan rendah pula pendapatan yang diterima oleh nelayan. Sejalan dengan itu sebagaimana dijelaskan pada lingkaran kemiskinan Nurske bahwa rendahnya pendapatan yang diterima berakibat kepada rendahnya tabungan. Selanjutnya rendahnya tabungan berimplikasi kepada rendahnya investasi. Sedangkan rendahnya investasi mengakibatkan kembali terjadi kekurangan modal.

\section{Jumlah Nelayan Menurut Kepemilikan Modal}

\begin{tabular}{l|c|c}
\hline $\begin{array}{c}\text { Kepe milikan Modal } \\
\text { Usaha }\end{array}$ & Jumlah & Prosentase \\
\hline Memiliki modal usaha & - & - \\
\hline $\begin{array}{l}\text { Tidak memiliki modal } \\
\text { usaha }\end{array}$ & 51 & 100 \\
\hline Jumlah & 51 & 100 \\
\hline
\end{tabular}

\section{Kepe milikan Tanah}

Berdasarkan penelitian yang dilakukan terhadap 51 responden tentang kepemilikan tanah bagi nelayan tradisional, diketahui pada Tabel berikut:

\begin{tabular}{l|c|c}
\hline $\begin{array}{c}\text { Kepemilikan Tanah } \\
\text { Perkarangan }\end{array}$ & Jumlah & Prosentase \\
\hline $\begin{array}{l}\text { Memiliki tanah } \\
\text { perkarangan }\end{array}$ & 47 & 75 \\
\hline $\begin{array}{l}\text { Tidak memiliki tanah } \\
\text { perkarangan }\end{array}$ & 4 & 25 \\
\hline \multicolumn{1}{c}{ Jumlah } & 51 & 100 \\
\hline
\end{tabular}

Bahwa 75 persen responden memiliki tanah perkarangan dan 25 persen responden tidak memiliki tanah perkarangan. Dengan demikian dapat diketahui, pada umumnya nelayan tradisional di Kelurahan Pontap memiliki tanah perkarangan, namun luas tanah sangat kecil dan masih dalam status milik Pemerintah Kota Palopo.

\section{Teknologi yang Digunakan}

Berdasarkan pengamatan, perahu yang digunakan oleh nelayan tradisional di Kelurahan Pontap, perahu tersebut menggunakan mesin tempel bermerek Honda dengan kapasitas mesin 5,5 PK. Perahu berukuran panjang 5 meter, lebar 1 meter dan tinggi 0,5 meter. Badan perahu terbuat dari kayu. Alat tangkap yang digunakan adalah jaring dan pencing. Umumnya mesin-mesin yang digunakan pada perahu-perahu tersebut kondisinya sudah tua yang ditunjukkan oleh banyaknya karatan yang menempel pada mesin.

\section{Ketergantungan nelayan pada pemilik modal}

Hasil Observasi Interaksi nelayan di Pontap ini berbentuk pola hubungan patron-klien. Patronklien melibatkan hubungan seseorang individu dengan status sosial ekonomi yang lebih tinggi (Patron) yang menggunakan pengaruh dan sumber dayanya untuk menyediakan perlindungan dan keuntungan bagi seseorang dengan status lebih rendah (Klien). Khusus nelayan tradisional hubungan yang bersifat patron-klien dapat dijelaskan patron adalah toke ikan atau toke perahu, yang lazim disebut dengan nelayan kaya. Klien adalah nelayan tradisional yang menggantungkan hidupnya kepada toke ikan atau toke-toke perahu terutama saat laut pasang, sehingga mereka tidak boleh melaut.

\section{Sistem bagi hasil ne layan dengan pemilik modal}

Sistem bagi hasil ialah nelayan pemilik modal (punggawa) memperoleh bagian lebih besar dari pada nelayan buruh, sehingga terjadinya ketimpangan pendapatan yang tajam antara 
nelayan pemilik dengan nelayan buruh. Ketimpangan dalam bagi hasil ini disebabkan oleh pola hubungan nelayan yang bersifat patron-klien, di mana hubungan ini telah membentuk ketergantungan nelayan buruh kepada nelayan pemilik sangat besar bukan hanya dalam modal kerja melainkan sampai kepada kebutuhan hidup keluarga nelayan buruh itu sendiri. Akibat dari ketergantungan itu, terbentuknya suatu jalinan hubungan yang lebih bersifat hubungan emosional antara nelayan buruh dengan nelayan punggawa. Konsekwensi dari hubungan itu adalah membuat nelayan buruh selalu menjadi korban eksploitasi dari nelayan pemilik modal atau ponggawa.

Sistem bagi hasil nelayan pemilik perahu dengan nelayan penumpang

Dalam kegiatan menangkap ikan di laut nelayan tradisional pemilik perahu dengan nelayan penumpang mempunyai resiko yang sama terhadap kegiatan usaha yang mereka jalankan. Sistuasi ini berdampak kepada sistem bagi hasil yang berlaku diantara mereka, di mana nelayan tradisional yang memiliki perahu memperoleh bagian yang sama besarnya dengan nelayan penumpang. Hal ini sesuai dengan sistem bagi hasil yang dilakukan oleh nelayan tradisional pemilik perahu dengan nelayan penumpang di Kelurahan Ponjalae Tapong, di mana menurut hasil penelitian yang dilakukan kepada 51 responden, tentang sistem bagi hasil yang berlaku antara nelayan tradisional pemilik perahu dengan nelayan penumpang, diketahui bahwa hasil tangkapan yang diperoleh oleh nelayan atas kerjasamanya dibagi sama dengan nelayan penumpang

\section{Peranan Lembaga Pemasaran}

Untuk mengembangkan pasar bagi produkproduk yang dihasilkan nelayan maka upaya yang dilakukan adalah mendekatkan masyarakat dengan pasar seperti eksportir komoditas perikanan. Keuntungan dari hubungan seperti ini yaitu nelayan mendapat jaminan pasar dan harga, pembinaan terhadap nelayan terutama dalam hal kualitas barang bisa dilaksanakan, serta sering kali nelayan mendapat juga bantuan modal bagi pengembangan usaha yang dihasilkan. Struktur pasar yang tidak menguntungkan nelayan ini disebabkan karena informasi yang kurang mengenai harga. Sehingga harga lebih sering dimonopoli oleh toke-toke ikan, di mana mereka membeli dengan harga murah dan menjualnya kepada eksportir dengan harga yang berlipat ganda.

\section{Peranan Lembaga Penyuluhan}

Upaya pemberdayaan masyarakat diharapkan mampu berperan meningkatkan kualitas sumber daya manusia terutama dalam bentuk dan merubah perilaku masyarakat untuk mencapai taraf hidup yang lebih baik. Pemberdayan masyarakat tidak lain adalah memberikan motivasi dan dorongan kepada masyarakat agar mampu menggali potensi dirinya dan berani bertindak memperbaiki kualitas hidupnya, melalui cara antara lain dengan pendidikan untuk penyadaran dan pemampuan diri mereka. Adapun perkembangan pemberdayaan tersebut dikenal dengan program penyuluhan

\section{Peranan Lembaga Perkreditan}

Sifat bisnis perikanan yang musiman, penghasilan yang tidak menentu serta beresiko tinggi sering menjadi alasan keengganan bank untuk memberikan bantuan modal usaha bagi nelayan. Sifat bisnis perikanan yang kenyal dengan resiko ini dan disertai dengan status nelayan yang umumnya rendah dan tidak mampu secara 
ekonomi membuat mereka kesulitan dalam memenuhi syarat-syarat yang diberlakukan oleh perbankan. Dengan memperhatikan kesulitan yang dihadapi oleh nelayan akan modal, maka salah satu alternatif adalah mengembangkan mekanisme pendanaan diri sendiri (self-financing mechanism)

\section{Bentuk Kemiskinan Nelayan Tradisional Kemis kinan Natural}

Nelayan tradisional di Kelurahan Ponjalae Tapong, sebagaimana yang telah kita bahas pada bagian sebelumnya bahwa terjadinya kemiskinan pada nelayan tradisional salah satunya disebabkan oleh faktor kualitas sumber daya manusia nelayan yang masih rendah, yang ditunjukkan oleh rendahnya tingkat pendidikan, tidak dimilikinya ketrampilan alternatif dan kurangnya pekerjaan alternatif.

Kurangnya ketrampilan alternatif tergambar dari ketrampilan yang dimiliki oleh nelayan tradisional. Di mana berdasarkan hasil penelitian yang dilakukan kepada 51 responden, tentang penguasaan ketrampilan alternatif, diperoleh data bahwa pada umumnya nelayan tradisional tidak menguasai ketrampilan alternatif. meskipun sumber daya alam yang terdapat di Kelurahan Ponjalae Tapong boleh dikatakan cukup memadai untuk dimanfaatkan sebagai sumber pandapatan, namun bila tidak didukung oleh pendidikan dan ketrampilan yang tinggi tentunya potensi sumber daya alam itu tidak mampu dikelola menjadi sumber pendapatan. Sehingga meskipun mereka tinggal di lingkungan sumber daya alam yang melimpah, tapi mereka tetap menjadi golongan masyarakat miskin.

\section{Kemiskinan Kultural}

Kelompok masyarakat seperti ini tidak mudah diajak berpartisipasi dalam pembangunan, tidak mau berusaha untuk memperbaiki dan merubah tingkat kehidupannya. Akibatnya tingkat pendapatannya rendah menurut ukuran yang dipakai secara umum. Dengan kata lain mereka miskin disebabkan karena faktor budaya seperti malas, tidak disiplin, boros dan lainnya. Pernyataan di atas signifikan dengan yang terjadi pada keluarga nelayan tradisional di Kelurahan Ponjalai dan Tapong, di mana budaya malas, tidak disiplin dan boros ini tercermin dalam sikap dan kebiasaan keluarga nelayan itu sendiri seperti dalam hal pemanfaatan waktu senggang, pengeluaran terhadap konsumsi rumah tangga dan budaya setempat. Sebenarnya banyak pekerjaan sampingan yang bisa dikerjakan meskipun dengan pendidikan dan ketrampilan yang terbatas, seperti salah satunya ialah bekerja sebagai buruh pada proyek-proyek yang dilaksanakan di Kecamatan Wara Timur, tapi mereka dengan berbagai alasan tidak mau melakukannya, bahkan mereka sudah merasa cukup dengan apa yang diperolehnya dari bekerja sebagai nelayan tradisional. Hal ini terbukti dari hasil penelitian yang dilakukan terhadap 51 responden tentang kegiatan yang dilakukan oleh nelayan ketika pulang dan tidak ke laut, diketahui bahwa umumnya nelayan menghabiskan waktunya dengan duduk di warung kopi dan hanya sebagian kecil yang memanfaatkan waktu senggangnya dengan melakukan pekerjaan sampingan. Dari segi konsumsi rumah tangga terhadap jenis barang dan jasa, nelayan tradisional di Kelurahan Ponjalae Tapong tergolong konsumtif untuk ukuran keluarga yang penghasilannya di bawah garis kemiskinan. Sehingga tidak heran bagi kita bila menemukan adanya jenis-jenis konsumsi barang dan jasa tertentu yang kurang wajar 
dibelanjakan oleh nelayan tradisional yang berpenghasilan di bawah garis kemiskinan, seperti merokok dan ngopi di warung kopi.

\section{Kemis kinan Struktural}

Pada nelayan tradisional di Kelurahan Ponjalae Tapong, di mana ketergantungan nelayan tradisional pada pemilik modal baik dalam kebutuhan modal, alat produksi dan kebutuhan keluarga tidak terlihat di sana. Dalam hal keperluan modal atau kebutuhan keluarga, nelayan tradisional meminjamnya pada saudara atau tetangga terdekat, sehingga secara emosional tidak adanya kewajiban bagi nelayan untuk menjual ikan kepada pemilik modal sebagai pembayarannya. Karena hubungan antara nelayan dengan pemilik modal bersifat hubungan horizontal. Sedangkan dalam hal kebutuhan alat produksi seperti perahu beserta alat tangkapnya, nelayan tradisional telah memperolehnya dari bantuan pemerintah Propinsi Sulawesi Selatan dan Pemerintah Kabupaten Wara Timur. Dari uraian di atas, dapat disimpulkan bahwa kemiskinan yang terjadi pada nelayan tradisional di Kelurahan Ponjalae Tapong bukan kemiskinan struktural. Artinya kemiskinan itu tidak disebabkan oleh adanya perbedaan struktur sosial masyarakat dan muncul oleh adanya suatu kebijakan tertentu dari pemerintah.

\section{SIMPULAN}

Kemiskinan yang terjadi pada nelayan tradisional di Kelurahan Ponjalae Tapong disebabkan oleh 3 (tiga) faktor yang sangat berpengaruh, yaitu:

1) faktor kualitas sumber daya manusia;

2) Faktor ekonomi; dan

3) faktor kelembagaan.
Kualitas suberdaya yang rendah terlihat dari minimnya tingkat pendidikan, keterbatasan keterampilan yang dimiliki (keterampilan alternative) oleh nelayan Pontap. Ketidakberdayaan ekonomi nelayan terlihat dari asset-aset yang dimiliki; kepemilikan tanah, modl kerja, serta teknologi modern nelayan ketidakberdayaan dalam bidang kelembagaan di buktikan dengan lemahnya peranan lembaga dalam berperan untuk meningkatkan kesejahteraan anggotanya melalui kegiatan ekonomi nelayan tradisional di Kelurahan Ponjalae Tapong, seperti keberadaan Koperasi Nelayan yang hanya bergerak dalam bidang simpan pinjam. Koperasi tidak melaksanakan perannya sebagai wadah dalam memasarkan hasil-hasil tangkapan nelayan dari hasil kerjanya.

Keberadaan balai penyuluhan pertanian dalam bidang perikanan belum aktif memberikan solusi denngan penyuluhan yang intesif kepada warga nelayan di Kelurahan Ponjalai dan Tapong, petugas penyuluhan lebih sering tidak berada di tempat.

Selanjutnya lembaga keuangan yang ada seperti Bank Perkreditan dan Koperasi Nelayan, tidak dapat diakses oleh nelayan karena persyaratan yang diberlakukan untuk mendapat pinjaman, mengharuskan nelayan untuk memberikan jaminan. Sementara jaminan itu tidak dimiliki oleh nelayan tradisional.

Bentuk Kemiskinan yang dialami oleh nelayan tradisional di Kelurahan Ponjalae Tapong tergolong kemiskinan natural dan kultural.

Kemiskinan natural terlihat dari banyaknya nelayan yang memiliki latar belakang sangat rendah, kualitas sumberdaya manusia yang ada 
belum mampu untuk diakselerasi, keberlimpahan sumber daya alam yang tersedia belum berkontribusi langsu dikarenakan keterbatasan kualitas sumberdaya manusia yang ada. Sumberdaya yang tersedia tidak mampu dikonversikan menjadi pendapatan untuk mengatasi kemiskinan yang ada.

Kemiskinan kultural terlihat dari sikap malas, gaya hidup konsumtif dan keberadaan pengaruh budaya adat istiadat yang berlaku di Kelurahan Ponjalae Tapong. Sikap malas ditandai dengan rendahnya pemanfaatan waktu luang saat tidak turun melaut. Nelayan lebih suka memanfaatkan waktu luang dengan kegiatan yang kurang produktif secara ekonomi. Waktu senggang seharusnya bias dimanfaatkan dengan kegiatan produktif seperti bekerja sampingan. Pola hidup konsumtif yang ada bisa dikurangi dengan pembatasan gaya hidup yang boros seperti pada pemenuhan kegiatan adat dan konsumsi rokok serta kegiatan nongkrong di warung kopi disaat tidak turun melaut. maksudnya hilangkan membeli barang dan jasa yang bukan merupakan kebutuhan dasar dan mendesak. Sedangkan dari segi budaya (adat) yang berlaku di Kelurahan Ponjalae Tapong adalah banyaknya acara adat yang memaksa nelayan untuk mengeluarkan biaya melebihi kemampuan pendapatannya, seperti pesta kawin, lain sebagainya.

\section{DAFTAR PUSTAKA}

Bengen. D.G. (2001). Pengelolaan Sumberdaya Wilayah Pesisir Secara Terpadu, Berkelanjutan dan Berbasis Masyarakat. Makalah pada Sosialisasi Pengelolaan Sumberdaya Berbasis Masyarakat. Bogor, 21-22 September 2001.
Friedmann, Jhon. (1992). Empowerment: The Politics Alternative Development. Chambridge, Blackwell. . (1995). Ekonomi dan Keadilan Sosial. Aditya Media. Yogyakarta.

Purwanti, P. (1994). Curahan Waktu dan Produktivitas Kerja Nelayan di Kabupaten Pasuruan. Program Pascasarjana. Universitas Gadjah Mada. Yogyakarta. Tesis. Tidak dipublikasikan.

Rahardja, Pratama. dkk. (2008). Pengantar Ilmu Ekonomi (Mikroekonomi \& Makroekonomi). Lembaga Penerbit Fakultas Ekonomi Universitas Indonesia. Jakarta.

Satria, Arif. (2001). Dinamika Modernisasi Perikanan: Formasi Sosial dan Mobilitas Nelayan. HUP. Bandung.

Sigit, H. (1993). Masalah Perhitungan Distribusi Pendapatan di Indonesia. Prisma. LP3ES. Jakarta.

Salim, E. (1984). Perencanaan Pembangunan dan Pemerataan Pendapatan. Yayasan Idayu. Jakarta.

Situmorang, Chazali. (2008). Penanganan Masalah Kemiskinan di Sumatera Utara (Poverty Reduction At North Sumatera). Jurnal Pembangunan.

Soedjatmoko. (1995). Dimensi Manusia dalam Pembangunan. dalam Bahtiar Chamsyah: Teologi Penanggulangan Kemiskinan. LP3ES. Jakarta.

Sudarso. (2008). Tekanan Kemiskinan Struktural Komunitas Nelayan Tradisional di Perkotaan. Jurnal Ekonomi. FISIP. Univesitas Airlangga. Surabaya.

Sudrajad, Iwan. (2008). Membangkit Kekuatan Ekonomi Nelayan. Jurnal Ekonomi. Ekonomi UNDIP. Semarang. Jawa Tengah.

Supradin dan Rahmania, Rohana. (2007). Kajian Kemiskinan Partisipatif Kota Kendari, Kota Bau-Bau, Kabupaten Konawe, 
Kabupaten Buton Provinsi Sulawesi Tenggara. Jurnal Pembangunan.

Surya, Alwin. (2009). Studi Deskriptif Potret dan Kehidupan Keluarga Nelayan Tradisional Medan Labuhan. Jurnal Sain, Teknologi, Kesehatan, Sosial, Ekonomi \& Imformatika. Volume 2, Nomor 1, Ferbruari 2009. Media Prima Sain 2009.

Suryawaty, Chriswardani. (2005). Memahami Kemiskinan Secara Multidimensional, Fakultas Kesehatan Masyarakat dan Magister Ilmu Kesehatan Masyarakat Jurnal Pembangunan. Universitas Diponegoro. Semarang. Jawa Tengah.

Tadaro, Michel.P. (2000). Pembangunan Ekonomi. Bumi Aksara.

Tarigan, Robinson. (2007). Ekonomi Regional, Teori dan Aplikasi. Bumi Aksara 
